\title{
A Comparison of Tools and Methods for Estimating GroundwaterSurface Water Exchange
}

Cremeans, M.M.; Devlin, J.F.; Osorno, T.C.; McKnight, Ursula S.; Bjerg, Poul Løgstrup

\section{Published in:}

Ground Water Monitoring \& Remediation

Link to article, DOI:

10.1111/gwmr.12362

Publication date:

2020

Document Version

Peer reviewed version

Link back to DTU Orbit

Citation (APA):

Cremeans, M. M., Devlin, J. F., Osorno, T. C., McKnight, U. S., \& Bjerg, P. L. (2020). A Comparison of Tools and Methods for Estimating GroundwaterSurface Water Exchange. Ground Water Monitoring \& Remediation, 40(1), 24-34. https://doi.org/10.1111/gwmr.12362

\section{General rights}

Copyright and moral rights for the publications made accessible in the public portal are retained by the authors and/or other copyright owners and it is a condition of accessing publications that users recognise and abide by the legal requirements associated with these rights.

- Users may download and print one copy of any publication from the public portal for the purpose of private study or research.

- You may not further distribute the material or use it for any profit-making activity or commercial gain

- You may freely distribute the URL identifying the publication in the public portal 
Research Paper/

\title{
A Comparison of Tools and Methods for Estimating Groundwater-Surface Water Exchange
}

\author{
M.M. Cremeans ${ }^{\text {a,b,e }}$, J.F. Devlin ${ }^{\text {a, e }}$, T.C. Osorno ${ }^{\text {c }}$, U.S. McKnight ${ }^{\text {d }}$, P.L. Bjerg ${ }^{d}$ \\ ${ }^{a}$ Department of Geology, University of Kansas, Lindley Hall Room 215, \\ 1475 Jayhawk Blvd., Lawrence, KS 66045, Tel. 785-864-4994, email: jfdevlin@ku.edu \\ ${ }^{\mathrm{b}}$ Current address is Shook, Hardy \& Bacon L.L.P., 2555 Grand Blvd. Kansas City, MO 64108- \\ 2613, Tel. 816-559-0428, email: mackenzie.cremeans@gmail.com \\ ${ }^{\mathrm{c}}$ Department of Geology, University of Kansas, Lindley Hall Room 215, \\ 1475 Jayhawk Blvd., Lawrence, KS 66045 \\ ${ }^{\mathrm{d}}$ Department of Environmental Engineering, Technical University of Denmark, Bygningstorvet \\ Building 115, 2800 Kgs. Lyngby, Denmark \\ ${ }^{\mathrm{e}}$ Corresponding author
}

Conflict of Interest: None

This article has been accepted for publication and undergone full peer review but has not been through the copyediting, typesetting, pagination and proofreading process, which may lead to differences between this version and the Version of Record. Please cite this article as doi: $10.1111 / \mathrm{gwmr} .12362$ 


\begin{abstract}
A comparison of tools for measuring discharge rates in a sandy streambed was conducted along a transect near the north bank of the Grindsted $\AA$ (stream). Four tools were evaluated at six locations spaced $3 \mathrm{~m}$ apart in the stream: mini-piezometers, streambed point velocity probes (SBPVPs), temperature profilers, and seepage meters. Comparison of the methods showed that all identified a similar trend of low to high groundwater discharges moving westward along the transect. Furthermore, it was found that the differences between discharges estimated from Darcy calculations (using the mini-pizometers), and SBPVPs were not statistically different from zero, at the $90 \%$ confidence level. Seepage meter estimates were consistently lower than those of the other two methods, but compared more reasonably with the application of a correction factor of 1.7, taken from the literature. In contrast, discharges estimated from temperature profiling (to a depth of $40 \mathrm{~cm}$ ) were found to be about an order of magnitude less than those determined with the other methods, possibly due to interferences from horizontal hyporheic flow. Where the various methods produced statistically different discharge estimations at the same location, it is hypothesized that the differences arose from method-specific sources of bias, including installation depths. On the basis of this work, practitioners interested in measuring flow across the GWSWI (groundwater-surface water interface) achieve the least variability with seepage meters and the SBPVP. However the accuracy of the seepage meter depended on a calibrated correction factor while that of the SBPVP did not.
\end{abstract}

Keywords: groundwater-surface water, comparison, tools, technology 


\section{Introduction}

Understanding flow across the groundwater-surface water interface (GWSWI) is important for water resource management, including issues pertaining to water pollution and water supply (Fleckenstein et al. 2010; Chow et al. 2016; Rønde et al. 2017). With the advent of legislation that protects groundwater dependent ecosystems (such as the EU Water Framework Directive), interest in the GWSWI has intensified (Fleckenstein et al. 2010). Though much effort has been expended to understand groundwater-surface water interactions, the spatial patterns and temporal dynamics of hyporheic flow processes are not adequately understood (Krause et al. 2014). In large part, gaps in understanding are due to the spatial and temporal heterogeneity of the sediments at the GWSWI, leading to complexities in flow patterns that can be difficult to fully describe (Keery et al. 2007; Käser et al. 2009; Hatch et al. 2006; Rosenberry et al. 2013).

To effectively characterize flow at the GWSWI the needs and challenges of the projects and sites should be considered when choosing characterization methods. For example, investigators can choose between in-well tools and methods (Halevy et al. 1968; Ballard 1996; Kearl 1997; Su et al. 2006, Osorno et al., 2018), tracer tests (McCallum et al. 2012; Haria et al. 2013; de Souza et al. 2015), and synoptic flow gauging (Harte and Kiah 2009) to investigate flow at the GWSWI. Side-by-side comparisons provide evidence of the relative strengths and weaknesses of the methods studied, assisting with the choice of the appropriate technologies for specific cases.

In this work, four technologies were compared: mini-piezometers (supporting a Darcybased calculation of seepage velocity); temperature profilers; seepage meters; and streambed 
point velocity probes (SBPVP). The Darcy approach is widely used and accepted, relatively simple to implement, low in materials cost, and offers the potential for time-series measurements. The method is also suitable for obtaining a high measurement density which can support high-resolution characterization of the GWSWI. In this work, hydraulic gradients were measured with mini-piezometers, and hydraulic conductivity $(K)$ with slug tests (Baxter and Hauer 2003; Rosenberry and LaBaugh 2008). However, the use of Darcy's Law has limitations related to uncertainties in estimates of $K$ and, in some cases, challenges related to obtaining accurate hydraulic gradients over small distances (Devlin and McElwee 2007; Harvey et al. 2013; Post and von Asmuth 2013).

Another GWSWI characterization technology, which has gained much attention over the past decade, is temperature profiling in the streambed (to delineate and quantify exchange rates) (Bredehoeft and Papadopulos, 1965; Krause et al. 2012; Irvine et al., 2017a; Coluccio 2018). Temperature-based methods are advantageous because they offer a fast and efficient way to delineate and estimate water flux, as with the temperature spear tool (Schmidt et al. 2006; Schmidt et al. 2007; Lautz 2010; Bhaskar et al. 2012; Irvine et al. 2016; Irvine et al., 2017b). They also offer the possibility of obtaining high spatiotemporal resolution (as with fiber-optic distributed temperature sensing) (Selker et al. 2006a; Selker et al. 2006b; Tyler et al. 2009; Hausner et al. 2011; Van de Giesen et al. 2012; Krause et al. 2012) and the possibility of time series data collection (Hatch et al., 2006; Keery et al., 2007; Shanafield et al., 2011). Temperature profiling depends on accurate estimates of groundwater temperature $\left(T_{L}\right)$, stream water temperature $\left(T_{s w}\right)$, and at least one measurement in the streambed (Schmidt et al. 2007). If multilevel temperature data within the streambed can be collected, as described by Jensen and Engesgaard (2011), further insight can be gained about the GWSWI. However, in some cases, 
both single measurement and multilevel sensor approaches have been shown to underestimate fluxes, by about a factor of 2, when compared to Darcy calculations and seepage meters (Schmidt et al., 2007; Jensen and Engesgaard, 2011). Schulz (2017) compared fluxes estimated from Darcy calculations, multisensory temperature profiling and SBPVP, and found the temperature methods to produce estimates approaching a factor of 10 lower than the other methods - though variability in the Darcy calculations was highly dependent on the method used to estimate hydraulic conductivity. Although temperature-based methods rely on a contrast between the temperature of groundwater and the temperature of surface water, which can vary seasonally (Krause and Blume 2013; Rose et al. 2013), they have been shown to effectively quantify and delineate exchange zones in field studies (Westhoff et al. 2011; Lu et al. 2017).

Seepage meters have been in use for examining GWSW interactions since the late 1970s (Lee 1977). Prior to that, they were developed to monitor water loss from irrigation canals (Israelsen and Reeve 1944). They operate by isolating a fixed area of the GWSWI, usually using the top section of a steel barrel, and either collecting water that discharges upward across the GWSWI or delivering water for infiltration downward across the interface. The collected or delivered water is temporarily stored in a plastic bag connected to the barrel section via plastic tubing. Some designs automate the procedure (e.g. Rosenberry and Morin, 2004). The change in water volume in the bag over time (per area) can be used to estimate a seepage flux. The design of seepage meters inherently leads to time-averaged flow measurements. Like mini-piezometers, seepage meters are inexpensive and relatively simple to construct.(Murdoch and Kelly 2003; Rosenberry 2005; Rosenberry and LaBaugh 2008; Rosenberry 2008; Kennedy et al. 2010; Solder et al. 2016). Seepage meters have been employed to great advantage in field studies, but care must be taken to avoid biases associated with early construction designs and their 
deployment in deep or fast-moving water. In particular, seepage meters have been associated with underestimations of flow, and sometimes depend on the application of calibration tests and correction factors (usually ranging from 1.05 to 1.7) (Rosenberry et al., 2005). Additionally, seepage meters are poorly suited for deployment at interfaces composed of hard substrates (Erickson 1981; Brock et al. 1982; Woessner and Sullivan 1984; Shaw and Prepas 1990; Blanchfield and Ridgeway1996; Zamora 2006).

The SBPVP, an adaptation of the point velocity probe (PVP), is a recent addition to the toolbox of methods for investigating the GWSWI. The PVP is a tool designed for installation in a dedicated borehole to determine aquifer groundwater velocity; the SBPVP is a reusable tool designed for installation in streambeds, or other surface water-groundwater interfaces, to determine flow across the GWSWI. Both devices estimate groundwater velocity using a minitracer test on the probe surface, which leads to velocity estimations that are independent of Darcy's Law calculations, and therefore provide a useful complement to established methods (Labaky et al. 2007; Devlin et al. 2012). Early testing provided encouraging evidence that the SBPVP was a viable tool with a range of operation of at least 18 to $2700 \mathrm{~cm} /$ day $($ Cremeans and Devlin 2017; Cremeans et al. 2018). The SBPVP was designed for use in unconsolidated material and is expected to be most effective in sandy sediments (Cremeans and Devlin, 2017). However, Schulz (2017) demonstrated that it can be used in some poorly sorted, coarser grained, and organic rich settings.

Recently, work aimed at developing and testing the SBPVP validated the new instrument against temperature profiling, and Darcy calculations based on data from minipiezometers (Cremeans and Devlin 2017; Cremeans et al. 2018). That work indicated good agreement between the Darcy flow estimates and SBPVP estimates; temperature profiling resulted in 
pronounced underestimates of groundwater discharge rates compared to the other methods. The earlier comparisons focused on the agreement of measured flow values (presented as seepage velocities) for the purposes of validation of the SBPVP and did not systematically and statistically assess the methods' intrinsic reproducibilities, or sensitivities to field variability, in side by side neighboring location tests. Furthermore, the previous work did not consider seepage meters in the comparisons, which is a notable gap in the technology assessments, since seepage meters are among the more commonly used instruments to measure flow across the GWSWI. The purpose of this work is to address the gaps in the previous comparisons by including data from seepage meters (as a fourth method considered for comparison) and additional statistical analyses (for the purpose of performance assessment comparisons). Further, this work provides practitioners with specific recommendations for streambed characterization investigations.

\section{Field Site}

Groundwater-surface water exchange was investigated in the bed of the Grindsted $\AA$, Denmark. Descriptions of the site have been given by Rønde et al. (2017) and by Maurya et al. (2018). Briefly, the Grindsted $\AA$ is a meandering stream with a variable depth ranging from $1 \mathrm{~m}$ to about $2.5 \mathrm{~m}$. The stream channel is between 8 and $12 \mathrm{~m}$ wide, with a mean discharge of about $1.7 \times 10^{5} \mathrm{~m}^{3} / \mathrm{d}$. It winds through predominantly sandy, Quaternary age sediments that range from 10 to $15 \mathrm{~m}$ thick. The sands are underlain by a $60 \mathrm{~m}$ sequence of Miocene sands with interbeds of clay and lignite. This sequence is underlain by a regional aquitard comprising Tertiary clays.

In this work, conducted in August, 2016, the upper layer of Quaternary sands that form the bed of the Grindsted $\AA$ were studied. The work focused on the bed nearest the north bank of the stream, along a well-studied meander (Sonne et al. 2017; Rønde et al. 2017; Cremeans et al. 2018). Each of the four methods to be compared (head measurements followed by Darcy-based 
calculations, temperature profilers, seepage meters and SBPVPs) were deployed at six equidistant measurement locations, spaced $3 \mathrm{~m}$ apart (Figure 1). The locations were selected based on the criterion that all instruments could be deployed to full advantage. This limited the study to the relatively shallow portions of the stream ( $<1.2 \mathrm{~m}$ deep) where the bed was close to horizontal.

Two sediment types were found to be present along the transect selected for study: silty sand, and sand, as determined by visual inspection. The change from silty sand to sand occurred gradationally, moving north and westward along the transect. The most abrupt change occurred between the fourth and fifth sampling locations. Despite the visual sediment variation along the specific transect studied here, the sediments in the Grindsted $\AA$ were generally found to be remarkably uniform in an extended reach of about $1 \mathrm{~km}$ surrounding the study area, based on the results of eight grain size analyses performed using HydrogeoSieveXL (Devlin 2015) on streambed samples collected by Sonne et al. (2017). Within this reach, $K$ values varied within $\pm 30 \%$ (one standard deviation) of the mean $(55 \mathrm{~m} / \mathrm{d}$ ), which is well within the typical range of uncertainty for $K$. A similar uniformity was found between two samples at varying depths at a single location ( 3 to $8 \mathrm{~cm}$ and 13 to $18 \mathrm{~cm}$ depth) a short distance upstream of the study site.

It is acknowledged that grain size analyses can only provide preliminary estimations of $K$, so slug test results from the immediate study area, previously reported by Cremeans et al. (2018), were used to support all Darcy calculations (Figure 1). Based on prior investigations of this site (Rønde et al., 2017), flow rates through the streambed were expected to be about $100 \mathrm{~cm} /$ day on average. In the streambank sediments, local variations between 4 and $200 \mathrm{~cm} /$ day were estimated (Rønde et al. 2017). 


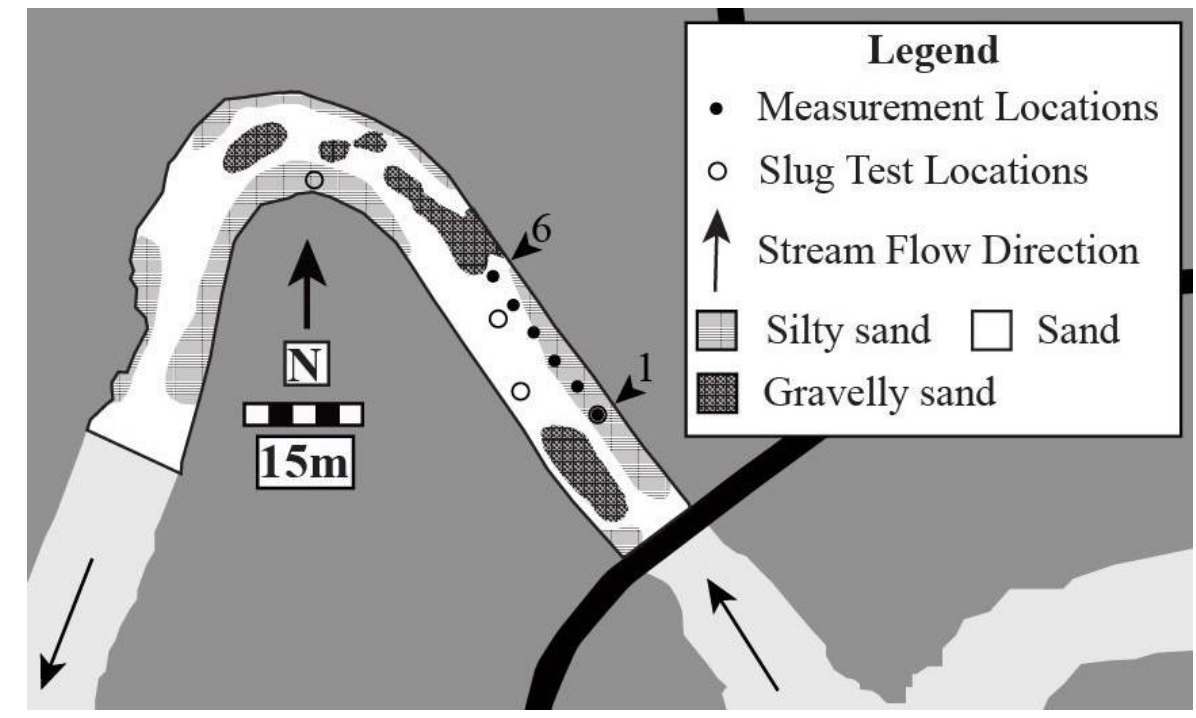

Figure 1: Map of Grindsted A stream bottom. The distribution of three observed sediment types, silty sand, sand, and gravelly sand, are shown. The 6 measurement locations where mini-piezometers, the SBPVP, temperature spears, and seepage meters measurements were made are shown as small solid circles. Slug test locations are indicated by open circles. Location 1 (large solid circle) was subjected to testing by all four methods and a slug test.

\section{Methods}

\section{Mini-Piezometers}

Hydraulic head data were collected from the Grindsted $\AA$ streambed using minipiezometers constructed from open-ended, clear polyvinyl chloride pipes with $2 \mathrm{~cm}$ inside diameters. The piezometers were installed to a depth of $40 \mathrm{~cm}$ (Figure 2) and allowed to equilibrate for 24 hours before data were collected with a Solinst Model 101 Water Level Meter. Hydraulic gradients across the GWSWI were calculated from the head data, using a stilling well to obtain the hydraulic head of the stream channel water (Baxter et al. 2000; Baxter and Hauer 2003).

Hydraulic conductivity values were obtained by slug testing (Butler, 1998). A drive point piezometer, with a $10 \mathrm{~cm}$ screen, was installed in each of the measurement locations with a 
pressure transducer (programmed to gather data every $0.5 \mathrm{~s}$ ). After the system had been left to equilibrate for 8 hours, water slugs of $1 \mathrm{~m}$ height were introduced to the piezometer and the falling head response was recorded. Four locations were chosen to represent the two observed sediment types in the transect examined: silty sand and clean sand. Two slug tests were conducted at each measurement location, resulting in eight total tests (all in situ at $40 \mathrm{~cm}$ depth) (Figure 1). In all cases, the two replicate tests exhibited nearly identical responses, so additional replicates were not considered necessary. All tests exhibited a straight-line overdamped response. Data from these tests were processed in AQTESOLV, where the $K$ for each sediment type was calculated with the Hvorslev method (Hvorslev 1951). In this work the measured $K$ was considered representative for both the vertical and horizontal directions of flow because the sediments were generally sandy, and testing was conducted in a single sediment stratum at each location. In such cases, factors of anisotropy can reasonably be expected to be low, between 1.3 and 1.6, as related in Cremeans et al. (2018).

Porosity $(n)$ was taken from previous work at a nearby landfill that suggested a porosity value between 0.30 and 0.35 for the Quarternary deposits in the area (Rügge et al., 1998). This range of values is consistent with the effective porosity of 0.32 estimated from the sediment grain-size curve based empirical relationship given by Urumovic and Urumovic (2016), using samples from the site. A value of 0.3 was used in all calculations, where Darcy flux estimates were converted to seepage velocities.

Seepage velocities, $v$, in the streambed were subsequently calculated from the following:

$$
v=-\frac{K i}{n}
$$


where $v$ is the seepage velocity $\left(\mathrm{LT}^{-1}\right), K$ is the hydraulic conductivity $\left(\mathrm{LT}^{-1}\right), i$ is the hydraulic gradient (unitless), and $n$ is the effective porosity (unitless).

\section{Temperature Gradient Method}

In this study, the temperature gradient method described in Schmidt et al. (2007) was applied using an Ebro TFN-520 Type K handheld thermometer. The device was deployed using a steel spear to measure the temperature gradients. This approach relies on the one-dimensional analytical solution:

$$
q_{z}=-\frac{\kappa_{f s}}{p_{f} c_{f} z} \ln \left(\frac{T_{Z}-T_{L}}{T_{0}-T_{L}}\right)
$$

where $q_{z}$ is Darcy flux in the vertical direction $\left(\mathrm{m} \mathrm{s}^{-1}\right), \kappa_{f s}$ is the thermal conductivity of the solidfluid system $\left(2.2 \mathrm{~J} \mathrm{~s}^{-1} \mathrm{~m}^{-1} \mathrm{~K}^{-1}\right)$ (Hopmans et al. 2002), $p_{f} c_{f}$ is the volumetric heat capacity of the fluid $\left(4.19 \times 10^{6} \mathrm{~J} \mathrm{~m}^{-3} \mathrm{~K}^{-1}\right), z$ is the depth of measurement $(0.4 \mathrm{~m}), T_{z}$ is the temperature at depth $\mathrm{z}$ $\left({ }^{\circ} \mathrm{C}\right.$ ) (ranged from 9.8 to $12.2{ }^{\circ} \mathrm{C}$ ), $T_{L}$ is the temperature of the groundwater which is fixed for all calculations $\left(8.6^{\circ} \mathrm{C}\right)$, and $T_{0}$ is the temperature at $z=0\left({ }^{\circ} \mathrm{C}\right)\left(\right.$ ranged from 10 to $\left.12.3{ }^{\circ} \mathrm{C}\right)$. This value was measured along with a surface water temperature $\left(T_{s w}=18{ }^{\circ} \mathrm{C}\right)$ and a bed-water temperature at depth $z\left(T_{z}\right)$ at every measurement location (Rasmussen et al., 2016). The $T_{z}$ measurements were made at $z=0.4 \mathrm{~m}$ in an effort to reach a zone beneath active horizontal hyporheic flow. That depth is also the deepest a temperature profilier could be installed in the Grindsted $\AA$ sediments without damage to the spear. To convert from specific discharge $\left(q_{z}\right)$ to seepage velocity, $q_{z}$ was divided by the effective porosity of the sandy bed, 0.3 . Temperature measurements were made by positioning the spear at the location of concern and waiting until the electronic readout reached a steady value. This usually required about a minute or less. More 
detailed descriptions of the use of temperature profilers and processing of temperature data in the Grindsted Å is given in Schmidt et al. (2007) and in Cremeans et al. (2018), respectively. The work reported here was conducted in the summer months when the stream water temperature was several degrees $\left({ }^{\circ} \mathrm{C}\right)$ higher than the groundwater temperature. This contrast in temperature made the application of the method favorable over the time of the study.

\section{Seepage Meters}

Seepage meters were constructed in accordance with recommendations in Murdoch and Kelly (2003) and Rosenberry (2008). Briefly, the devices used in this study were fabricated from plastic buckets $\left(\sim 30 \mathrm{~cm}\right.$ diameter; area $\left.(\mathrm{A})=706.8 \mathrm{~cm}^{2}\right)$ and installed to a depth of about $12 \mathrm{~cm}$ (Figure 2). The collection bag (with a maximum volume of $1 \mathrm{~L}$ ) was connected to the bucket with $1.1 \mathrm{~cm}$ inner diameter tubing. To avoid head losses due to the movement of water in the stream channel, the bag was placed inside a container where the water surrounding it was stationary. The seepage meters were left to equilibrate for 24 hours prior to attaching the bag and conducting flux measurements. Each test began with $250 \mathrm{~mL}$ of water in the bag. Because this reach of the stream was gaining, the bag filled with water over time. A typical test allowed the bag to fill over a 30 to 90 -minute period to a total volume not exceeding $750 \mathrm{~mL}$, to minimize head losses related to resistance of bag inflation. Seepage velocities were estimated from,

$$
v=\frac{V}{A \times t \times n}
$$

where $V$ is the volume of water collected in the bag and $t$ is the time over which the volume was collected. For the purposes of comparison, seepage velocities determined this way were not initially subject to calibration or correction factors. 


\section{Streambed Point Velocity Probes}

In each of the six measurement locations, the SBPVP was installed 5-10 $\mathrm{cm}$ below the streambed with a hyporheic shield in place to prevent any influence from horizontal flow on the upward velocity measurements (Cremeans and Devlin 2017, Cremeans et al., 2018). Tests were conducted with tracer injection volumes ranging from $0.1 \mathrm{~mL}$ to $0.4 \mathrm{~mL}$ and with tracer concentrations ranging from $1 \mathrm{~g} / \mathrm{L} \mathrm{NaCl}$ to $2 \mathrm{~g} / \mathrm{L} \mathrm{NaCl}$, which have been shown to exert no discernable density effects on flow in PVP tests in sandy media (Schillig et al. 2014). The tests required between $\sim 30$ minutes and $\sim 180$ minutes to complete. Data collection was accomplished using a Campbell Scientific CR1000 datalogger set up to collect data at 2 second intervals. Data were processed using the software package VelProbePE (Schillig 2012).

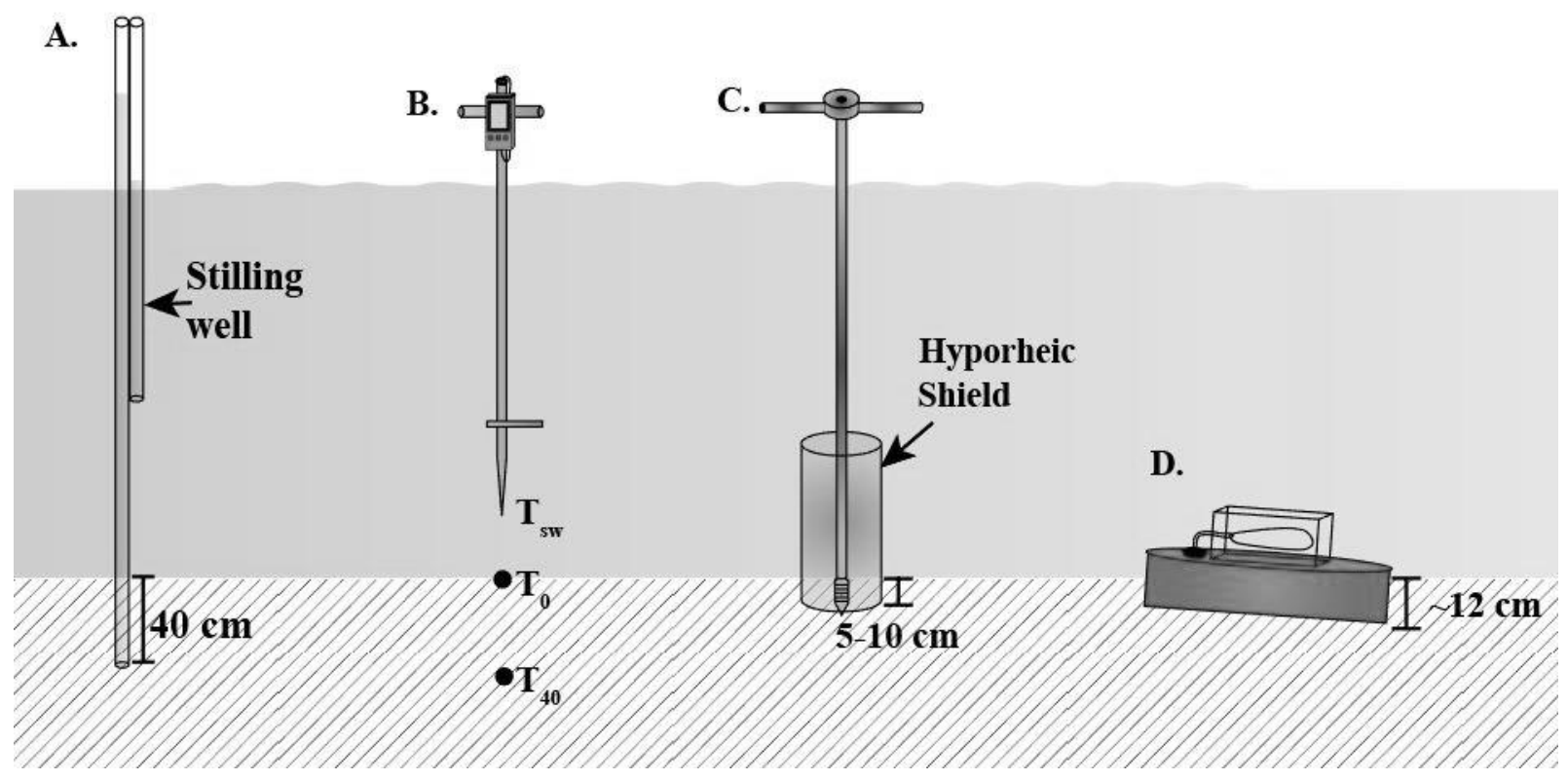

Figure 2: Schematic representations of the four methods compared in this study. A. Minipiezometers. B. Temperature profilers. C. SBPVPs. D. Seepage meters. See text for details. 


\section{Results and Discussion}

\section{Reproducibility of measurements}

Each of the four methods under study was evaluated for its intrinsic variability, i.e., variability originating in the procedures and hardware, by conducting duplicate measurements without relocating the instrumentation - at each location along the study transect (Table 1). With the exception of a single pair of seepage meter tests at location 1, all duplicate tests produced results within 5\% of each other (Figure 3a). The anomalous test was reproducible within 10\%, and involved duplicate velocities only $1.3 \mathrm{~cm} / \mathrm{d}$ apart. In subsequent tests, variations within each method were therefore ascribed to actual differences in flow in the streambed.

Table 1: Measured seepage velocities by four methods: SBPVP = streambed point velocity probe, MP = Darcy methods using minipiezometers, $\mathrm{SM}=$ seepage meter, $\mathrm{T}=$ temperature profiling. Data from two surveys are shown. The first (left) were previously reported by Cremeans et al. (2018), and the second (right) were collected for the analysis of intrinsic reproducibility of the methods.

\begin{tabular}{|c|c|c|c|c|c|c|c|c|}
\hline \multirow[b]{2}{*}{ Location } & \multicolumn{4}{|c|}{$\begin{array}{l}\text { Transect velocities }(\mathrm{cm} / \mathrm{d}) \\
\text { from Cremeans et al., }(2018)\end{array}$} & \multicolumn{4}{|c|}{$\begin{array}{l}\text { Transect velocities }(\mathrm{cm} / \mathrm{d}) \text {, } \\
\text { duplicate survey }\end{array}$} \\
\hline & $\underline{\text { SBPVP }}$ & $\underline{\mathrm{MP}}$ & $\underline{S M}$ & $\underline{T}$ & $\underline{\text { SBPVP }}$ & $\underline{\mathrm{MP}}$ & $\underline{\mathrm{SM}}$ & T \\
\hline 1 & 5.50 & ND & 12.90 & 1.10 & 18.1 & ND & 13.5 & 1.08 \\
\hline 1 & & & & & 18.1 & ND & 12.2 & 1.11 \\
\hline 2 & 61.0 & 111 & 25.1 & 1.00 & 47.0 & 110.8 & 25.4 & 1.04 \\
\hline 2 & & & & & 47.2 & 110.8 & 24.8 & 1.03 \\
\hline 3 & 50.0 & 27.7 & 19.3 & 5.70 & 50.0 & 27.6 & 19.4 & 5.62 \\
\hline 3 & & & & & 50.0 & 27.8 & 19.1 & 5.67 \\
\hline 4 & 45.5 & 55.4 & 26.3 & 6.50 & 45.8 & 56.0 & 25.8 & 6.51 \\
\hline 4 & & & & & 45.2 & 54.8 & 26.9 & 6.47 \\
\hline 5 & 173 & 111 & 55.8 & 5.80 & 173 & 111 & 55.5 & 5.80 \\
\hline 5 & & & & & 173 & 111 & 56.1 & 5.84 \\
\hline 6 & 150 & 138 & 56.5 & 19.30 & 150 & 138 & 62.1 & 19.3 \\
\hline 6 & & & & & 150 & 138 & 61.5 & 19.3 \\
\hline
\end{tabular}



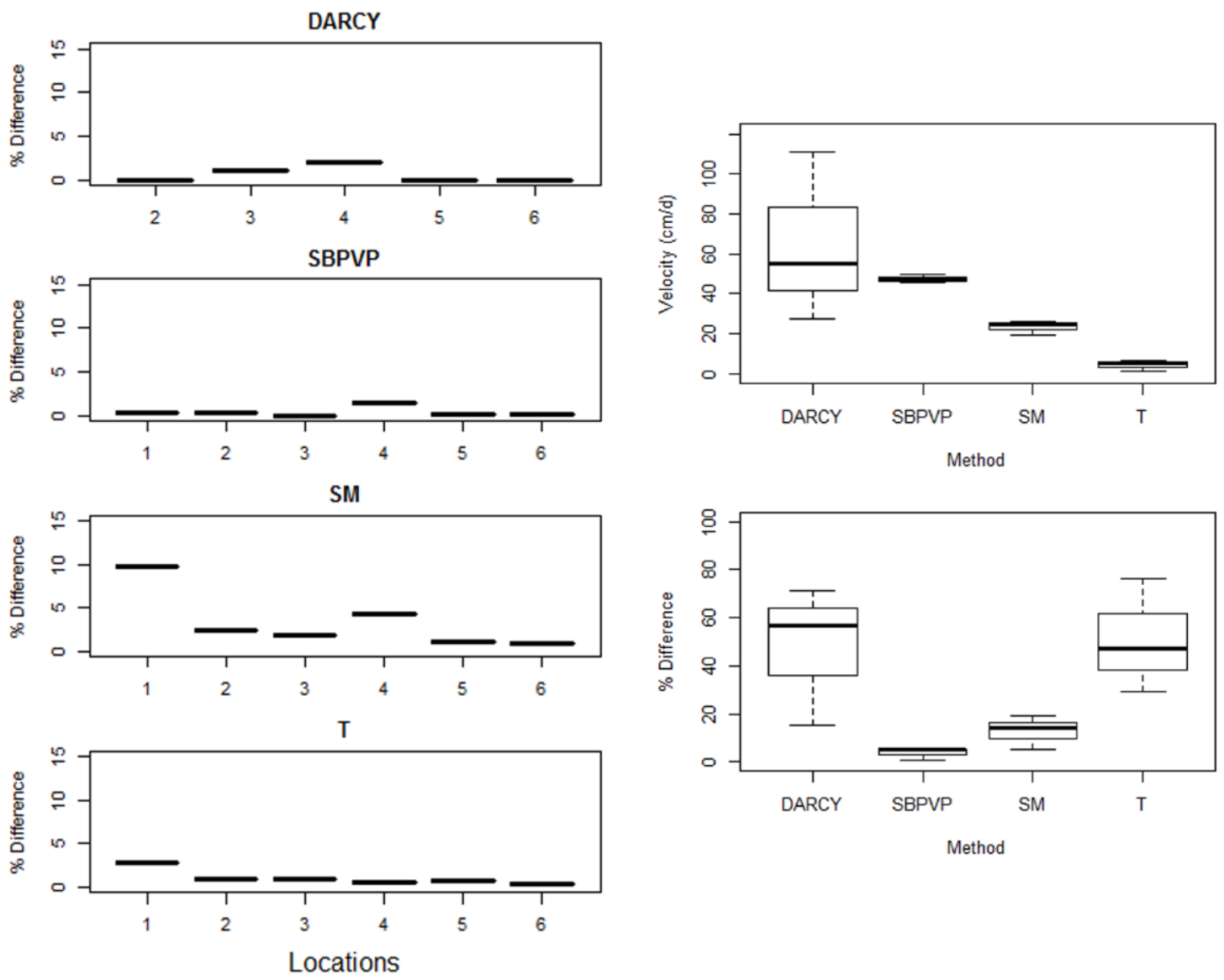

Figure 3: (a) Boxplots of instrument reproducibility by method for each location tested. All methods yielded back-to-back test variations less than 5\%, except one seepage meter test at location 1 (10\%). (b) Variability of velocity estimates at locations 2,3 and 4. (c) Percent differences from the average values calculated for locations 2,3 and 4 .

The sediments at locations 2, 3 and 4 were visually identical and afforded the opportunity to assess the reproducibility of the methods implemented at similarly characterized neighboring locations. The estimated velocities (from duplicate measurements) for each of these 3 locations was between 47 and $64 \mathrm{~cm} / \mathrm{d}$ (SBPVP and Darcy, respectively), $23 \mathrm{~cm} / \mathrm{d}(\mathrm{SM})$ and $4 \mathrm{~cm} / \mathrm{d}$ (T), confirming previously noted consistencies between Darcy and SBPVP measurements, and apparently large underestimations by the temperature profiling method (Cremeans et al., 2018) 
(Figure 3b). Assuming the Darcy and SBPVP most accurately reflect the upward velocities in the streambed, this work indicates that the SM apparatus employed was also subject to an apparent negative bias of about a factor of 2 to 3 , which is slightly higher than the range of correction factors reportedly used with this technique (1.05 to 1.7, according to Rosenberry et al., 2005).

The variabilities (i.e., differences between the location specific values and the overall three-location average velocity) across locations 2, 3, and 4 were relatively small for the SM and SBPVP, averaging $< \pm 15 \%$ and $< \pm 5 \%$, respectively (Figure 3c). The Darcy and T methods exhibited larger variabilities, averaging about $\pm 50 \%$ in each case. In all cases, the extrinsic variability was larger than the intrinsic variability, indicating that all methods were sensitive enough to the flow in the streambed to distinguish flow from instrument noise. It is acknowledged that the extrinsic variability includes artifacts that may have arisen from the installation procedures, which would be expected to be most pronounced for the deeper installations, where the potential for sediment perturbation was the greatest. This may partially explain why the Darcy and temperature methods were the most prone to uncertainty of the four methods (Figure 3c), i.e., they required the deepest installations.

\section{Transect-wide comparison of methods}

The Darcy method is arguably the most accepted of the methods studied here. Therefore, in this work it was used as the benchmark for comparison. For consistency with previous work, velocities from the Cremeans et al. (2018) data set are used in the subsequent analysis, but the same trends were found to apply to the data set collected for duplicate analysis discussed above, establishing that over the duration of data collection ( $\sim$ week) flow conditions in the streambed remained quite consistent. A single exception to this observation occurred at the first location, where the Cremeans et al. (2018) SBPVP dataset reported a $v$ of $5.5 \mathrm{~cm} / \mathrm{d}$ and the duplicate 
dataset found $v=18.1 \mathrm{~cm} / \mathrm{d}$, about a three-fold difference (Table 1). This difference is not large compared to the overall range of $v$ reported in Table 1 (up to $173 \mathrm{~cm} / \mathrm{d}$ for the SBPVP), and is attributed to either small scale variations in the streambed sediments or slight differences in the plant root presence at the measurement locations (co-located between datasets to within a few centimeters).

Over the full transect, i.e., locations 1 to 6 , all four methods revealed a qualitatively consistent trend: lower seepage velocities at the eastern end, and larger flow rates at the western end of the transect. Positive correlations between each method and the Darcy calculations of velocity reflect this agreement (Figure 4). This observation is consistent with expectations based on the sediment types observed on the streambed (Figure 1); the eastern end of the transect was characterized by silty sand and the western end by sand. The difference in upward seepage velocities ranged more than two orders of magnitude across the test zone, from a few centimeters per day at location 1 to $173 \mathrm{~cm} /$ day, depending on the method used, at locations 5 and 6 (Table 1). 
a)

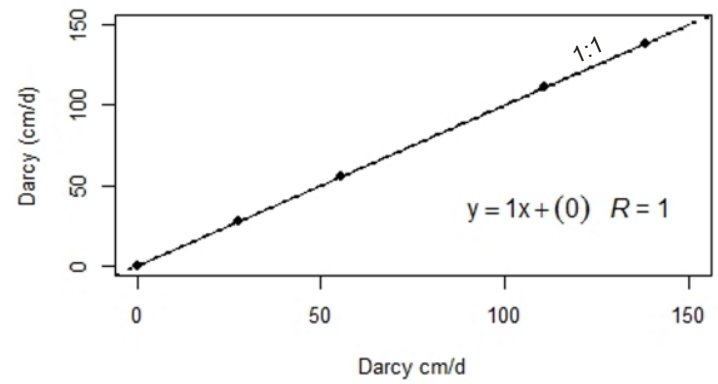

c)

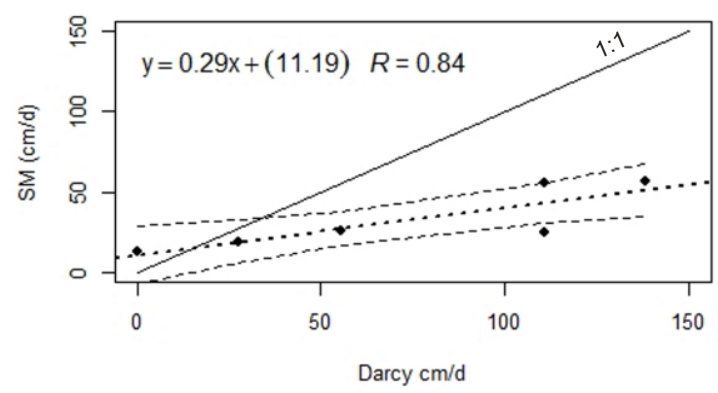

b)

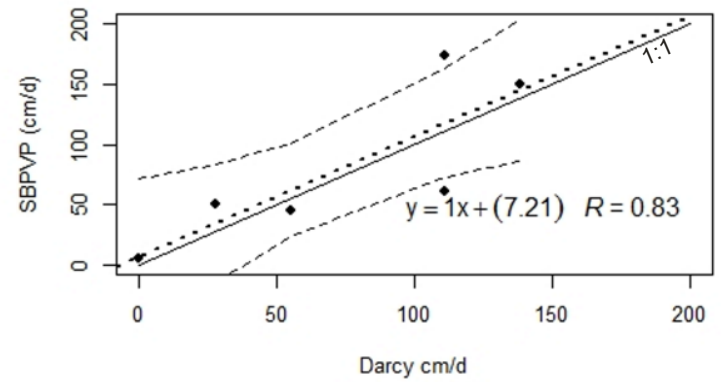

d)

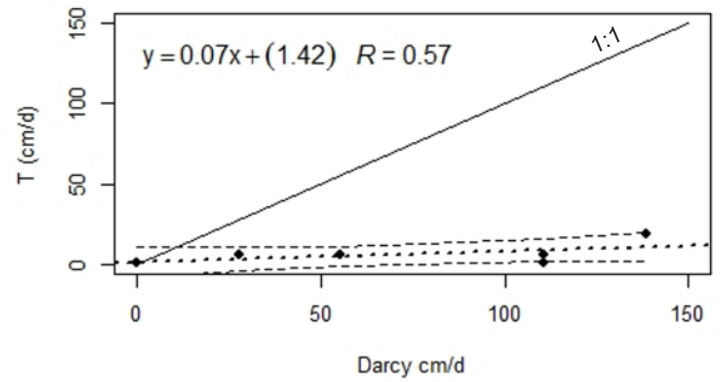

Figure 4: Correlations between velocity measurements of all four methods relative to the Darcy estimates, using minipiezometers. Symbols denote measurement values, broken lines represent best fit linear trends and 90\% confidence intervals, solid lines represent 1:1 lines. Negatively biased velocity estimates, relative to Darcy estimates, plot below the 1:1 line.

The correlations plotted in Figure 4, are characterized by positive correlation coefficients $(\mathrm{R})$ and the slopes of the regression lines range from 0.07 to 1 . To aid in the visual assessment of the data sets, Figure 4 includes the 1:1 lines for each correlation plot. Methods producing estimates of seepage velocity consistent with the Darcy-derived estimates would plot near these 1:1 lines. Of the methods tested, only the SBPVP method produced a correlation line with confidence intervals $( \pm 90 \%)$ that enclosed the 1:1 line. While the overall correlation between the Darcy and SBPVP data is strong, the agreement on a point by point basis is not perfect, as shown by the scatter in points around the 1:1 line in Figure $4 \mathrm{~b}$, and a correlation coefficient of 0.87 (i.e., <1). The strong correspondence between the Darcy and SBPVP method 
results is consistent with observations by Cremeans et al. (2018) in their consideration of 92 sampling locations on the same stream meander. They reported a slope of 1.08 in a SBPVP vs. Darcy scatterplot, including seepage velocities up to $27 \mathrm{~m} / \mathrm{d}$. The tendencies for the $\mathrm{SM}$ and T measurements to underestimate seepage velocities, compared to the Darcy and SBPVP methods persisted over the full range of velocity magnitudes measured in this work.

\section{Discussion}

Of the four technologies assessed, only two produced statistically similar results: the Darcy method and the SVPVP method. The SM method underestimated the seepage velocities compared to the Darcy and SBPVP methods. This is shown in Figure 4 and was further assessed by examining the data with the Student's $t$ test. The average velocity along the transect measured by each method was compared to that determined by the Darcy method. The SBPVP velocity average was found to have an $85 \%$ probability of being identical to the Darcy-derived velocity average. This probability declined to $13 \%$ for the SM velocity average and $3 \%$ for the T velocity average.

The SM method sometimes involves the application of a calibration factor. Applying a hypothetical factor of 1.7 to the SM velocities measured here, which represents the highest factor related by Rosenberry and Morin (2004), increased the probability that the SM and Darcy velocity averages were the same (i.e., that the difference trendline slope is equal to zero) from $13 \%$ to about $50 \%$. The negative bias encountered here is most likely caused by unanticipated head losses in the seepage meter apparatus, despite attempts to minimize this problem in the unit's construction. This result illustrates a limitation of the seepage meter method: a calibration step may be required for highest confidence in the measurements. Since there is no guarantee 
that a single calibration test would apply to all conditions at a site, practical limitations for the accuracy of the method persist.

The temperature profiling method also underestimated the seepage velocities - in this case by a factor exceeding about 10 . This result coincides with previous observations by Cremeans et al. (2018) and Schulz (2017). Underestimations by the temperature profiling method have been attributed to errors in the $\kappa_{f s}$ parameter, changes in flow between sampling events, uncertainty in the end-member temperatures $\left(T_{o}\right.$ and $\left.T_{z}\right)$, and the effects of horizontal hyporheic flow (Schmidt et al., 2007; Jensen and Engesgaard, 2011; Cremeans et al., 2018), The magnitude of the underestimation in this case exceeds what would be expected from these sources of parameter uncertainty. The close timing of the measurements (within a few days) argues against seasonally-dependent hydraulic conditions as the source of the disagreement. Diurnal variations in flow are also considered an unlikely source of bias, since all measurements were made during daylight hours and overlapped in timing. The consistent, pronounced negative bias in the $\mathrm{T}$ velocities should not have occurred under these conditions if true variations in flow were occurring. Thus, as Cremeans et al. (2018) argued, hyporheic flow is a likely cause. Further work is needed to quantify the hyporheic flow field and test this hypothesis. On the basis of the above testing results, it is concluded that the Darcy and SBPVP methods provided the estimates of seepage velocity in the Grindsted $\AA$ sediments with the (likely) highest accuracy (the term 'likely' is used here because the actual velocities cannot be known with $100 \%$ certainty). The lack of calibration needed for either of these methods also favors them as convenient and practical field techniques.

Precision of the measurements was also assessed and found to be different among the various methods. All methods performed well in back-to-back tests to assess intrinsic 
measurement reproducibility (Figure 3a). Only the seepage meter yielded a variation in duplicates greater than 5\%. However, even in that case, the variation was still less than $10 \%$ and corresponded to measured seepage velocities less than $1 \mathrm{~cm} / \mathrm{d}$ apart.

There was greater contrast in the replicate tests performed at neighboring locations 2,3 and 4. In those cases, the least variability (i.e. difference in location-specific values from the 3location average) was associated with the SBPVP and SM tests, which were about 5\% and 15\%, respectively. We note that the percentage for the SM method slightly underestimates the SM performance. Since the method yielded velocity estimates with lower magnitudes but the same variability in the absolute values of the differences across locations $(\sim 5 \mathrm{~cm} / \mathrm{d})$ as the SBPVP method, higher variability on a percent basis resulted.

The Darcy and T methods exhibited variations in velocity up to about $60 \%$ each, notably less precise than the SM and SBPVP methods (Figure 3c). It may be noteworthy that both the SM and SBPVP methods relied on minimal penetration of the streambed, capturing and measuring flow very close to the GWSWI. As noted in the "Reproducibility of measurements" section, the Darcy and $\mathrm{T}$ methods both depended on instrumentation that penetrated the streambed to a depth of about $0.4 \mathrm{~m}$. For those methods, reproducibility across locations depended on a high degree of spatial uniformity both laterally and vertically, to about a half meter depth. Perturbations in the streambed due to instrument installation are also more likely to be problematic with deeper installations. These factors could account for the lower spatial precision that was observed in these methods.

Another potential source of measurement variability between methods is the time required to collect a measurement. The Darcy-based estimates, and those based on temperature measurements, involved data collection that required only a few minutes to complete (i.e., about 
3 to 5 minutes), while the seepage meter and SBPVP measurements require data collection over longer time periods (30 to 90 minutes or 30 to 180 minutes, respectively). In this study, we assumed steady state flow to permit direct comparisons between the various methods. With steady state flow, data collection time should not affect data variability. Given the generally steady flow in the surrounding aquifer reported by Rønde et al. (2017), and the relatively short times over which the data sets in Table 1 were each collected (all within a few days), and the high degree of reproducibility in measurements presented here, the assumption is considered reasonable. It is also noted that the highest extrinsic variabilities were recorded for the Darcy and T methods, which were the fastest methods. This argues against data collection time as a major source of variability in this study. In future work, care should be taken to account for deviations from the steady state flow assumption so that variability between methods is properly ascribed.

\section{Conclusions}

In summary, it is concluded that all methods tested exhibited a low intrinsic variability that was on the order of $\pm 0.5 \mathrm{~cm} / \mathrm{d}$ or less. Extrinsic factors related to the streambed sediments or installation effects, contributed to higher levels of operational variability. These amounted to $< \pm 5 \% \mathrm{~cm} / \mathrm{d}$ for the SBPVP and $< \pm 15 \%$ for the seepage meter methods. Extrinsic variability was higher for the instruments that relied on deeper installations $(\sim 0.4 \mathrm{~m})$. In these cases the variability rose to about $\leq \pm 50 \%$ in each of the Darcy and temperature methods, on average. It is noted that the extrinsic variability here was assessed on the basis of the particular conditions in a short reach of the Grindsted streambed. These results could deviate somewhat from those derived from investigations at other sites. 
On the basis of the above work, it is recommended that for sandy bottom streams, like the Grindsted $\AA$, the SBPVP tool be the preferred instrument for streambed characterization. It provided seepage velocity estimates with the best combined (likely) accuracy and precision without calibration. The SBPVP tool is not widely available, so in its absence it is recommended that seepage meters, properly calibrated, be considered the preferred method, when permitted by stream depth, bed sediment type, and topography. The seepage meter was the most precise measurement tools tested here. The methods requiring installations deeper than a few centimeters, i.e., the Darcy method and temperature profiling, both exhibited relatively poor measurement precision. Darcy-based estimates of seepage velocity were similar to those from the SBPVP in apparent overall (likely) accuracy. The simplified temperature profiling method applied here appeared to underestimate flow rates substantially. Therefore, the Darcy approach is recommended primarily as an independent validation method for the SBPVP or seepage meter measurements. Despite issues with accuracy, the temperature profiling proved to be very fast to implement, and was effective in identifying the general trend of increasing flow along the transect. Therefore, it is recommended that this method be used as a screening tool to help identify zones worthy of more detailed examination by other methods. The possibility that a more sophisticated temperature profiling method might have improved the velocity estimates deserves more attention in future work.

\section{Acknowledgements}

The authors thank the Madison and Lila Self Graduate Fellowship for support of Mackenzie Cremeans, the University of Kansas Doctoral Research Fund, Kansas Geological Foundation, and GEOCON (Innovation Fund Denmark, contract no. 1305-00004B) for 
supporting the work. From the Technical University of Denmark, Bent Skov is acknowledged for assistance in the field. From the Kansas Geological Survey, Geoff Bohling is acknowledged for his assistance with the statistical analysis.

\section{References}

Ballard, S. 1996. "The in situ permeable flow sensor: A ground-water flow velocity meter." Ground Water 34 (2): 231-240. https://doi.org/10.1111/j.1745-6584.1996.tb01883.x.

Baxter, C. and F.R. Hauer. 2000. "Geomorphology, hyporheic exchange, and selection of spawning habitat by bull trout (salvelinus confluentus)." Canadian Journal of Fisheries and Aquatic Sciences 57 (7): 1470-1481. https://doi.org/10.1139/f00-056.

Baxter, C., F.R. Hauer, and W.W. Woessner. 2003. "Measuring groundwater-stream water exchange: new techniques for installing mini-piezometers and estimating hydraulic conductivity." Transactions of the American Fisheries Society 132 (3):493-502. https://doi.org/10.1577/1548-8659(2003)132<0493:MGWENT>2.0.CO;2.

Bhaskar, A.S., J.W. Harvey, and E.J. Henry. 2012. "Resolving hyporheic and groundwater components of streambed water flux using heat as a tracer." Water Resources Research, 48 (8). https://doi.org/10.1029/2011WR011784.

Blanchfield, P.J. and M.S. Ridgway. 1996. "Use of seepage meters to measure groundwater flow at brook trout redds." Transactions of the American Fisheries Society 125 (5): 813-818. https://doi.org/10.1577/1548-8659(1996)125<0813:UOSMTM>2.3.CO;2.

Bredehoeft, J.D., Papadopulos, I.S. 1965. Rates of vertical groundwater movement estimated from the Earth's thermal profile. Water Resources Research, 1(2), 325-328.

Brock, T.D., D.R. Lee, D. Janes, and D. Winek. 1982. "Groundwater seepage as a nutrient source to a drainage lake; Lake Mendota, Wisconsin." Water Research 16 (7):1255-1263. https://doi.org/10.1016/0043-1354(82)90144-0.

Butler, J.J. 1998. The Design, Performance, and Analysis of Slug Tests. Boca Raton, FL: CRC Press LLC. ISBN: 1-56670-230-5.

Chow, R., M.E. Frind, E. Frind, J.P. Jones, M.R. Sousa, D.L. Rudolph, J.W. Molson, and W. Nowak. 2016. "Delineating baseflow contribution areas for streams - A model and methods comparison." Journal of Contaminant Hydrology 195: 11-22. https://doi.org/10.1016/j.jconhyd.2016.11.001.

Coluccio, K. 2018. "A comparison of methods for estimating groundwater-surface water interactions in braided rivers." MS Thesis, University of Canterbury.

Cremeans, M.M. and J.F. Devlin. 2017. "Validation of a new device to quantify groundwatersurface water exchange." Journal of Contaminant Hydrology 206: 75-80. https://doi.org/10.1016/j.jconhyd.2017.08.005.

Cremeans, M.M, J.F. Devlin, U.S. McKnight, and P.L. Bjerg. 2018. "Application of a New Device to Quantify Groundwater-Surface Water Interactions." Journal of Contaminant Hydrology 206: 75-80. https://doi.org/10.1016/j.jconhyd.2017.08.005. de Souza, E.L., P. Galvão, R. de Almeida, C. Pinheiro, M. Baessa, and M. Cabral. 2015. "Stable isotopes studies in the Urucu Oil Province, Amazon Region, Brazil." Journal of Water Resource and Protection 7: 131-142. https://doi.org/10.4236/jwarp.2015.73011. 
Devlin, J.F. and C.D. McElwee. 2007. "Effects of measurement error on horizontal hydraulic gradient estimates." Groundwater 45 (1): 62-73. https://doi.org/10.1111/j.17456584.2006.00249.x.

Devlin, J.F., P.C. Schillig, I. Bowen, C.E. Critchley, D.L. Rudolph, N.R. Thomson, G.P. Tsoflias, and J.A. Roberts. 2012. "Applications and implications of direct groundwater velocity measurement at the centimetre scale." Journal of Contaminant Hydrology 127 (1-4): 3-14. https://doi.org/10.1016/j.jconhyd.2011.06.007.

Devlin, J.F. 2015. "HydrogeoSieveXL: an Excel-based tool to estimate hydraulic conductivity from grain-size analysis." Hydrogeology Journal 23: 837-844. https://doi.org/10.1007/s10040-015-1255-0.

Erickson, D.R. 1981. "The hydrogeology of Williams Lake, Minnesota with special emphasis on quantification of littoral ground water contributions using seepage meters and wells." $\mathrm{PhD}$ dissertation, University of Minnesota.

Fleckenstein, J.H., S. Krause, D.M. Hannah, and F. Boano. 2010. "Groundwater-surface water interactions: New methods and models to improve understanding of processes and dynamics." Advances in Water Resources 33 (11): 1291-1295. https://doi.org/10.1016/j.advwatres.2010.09.011.

Halevy, E., H. Moser, O. Zellhofer, and A. Zuber. 1968. "Borehole dilution techniques: A critical review." Technical report, IAEA, Vienna.

Haria, A.H., P. Shand, C. Soulsby, and S. Noorduijn. 2013. "Spatial delineation of groundwatersurface water interactions through intensive in-stream profiling." Hydrological Processes 27 (4): 628-634. https://doi.org/10.1002/hyp.9551.

Harte, P.T. and R.G. Kiah. 2009. "Measured river leakages using conventional streamflow techniques: the case of Souhegan River, New Hampshire, USA.” Hydrogeology Journal 17 (2): 409-424. https://doi.org/10.1007/s10040-008-0359-1.

Harvey, J.W., J.K. Böhlke, M.A. Voytek, D. Scott, and C.R. Tobias. 2013. "Hyporheic zone denitrification: Controls on effective reaction depth and contribution to whole stream mass balance." Water Resources Research 49 (10): 6298-6316. https://doi.org/10.1002/wrcr.20492.

Hatch, C.E., A.T. Fisher, J.S. Revenaugh, J. Constantz, and C. Ruehl. 2006. "Quantifying surface water-groundwater interactions using time series analysis of streambed thermal records: Method development." Water Resources Research 42 (10). https://doi.org/10.1029/2005WR004787.

Hausner, M.B., F. Suárez, K.E. Glander, N. van de Giesen, J.S. Selker, and S.W. Tyler. 2011. "Calibrating single-ended fiber-optic raman spectra distributed temperature sensing data." Sensors 11 (11): 10859-10879. https://doi.org/10.3390/s111110859.

Hopmans, J.W., J. Simunek, K.L. Bristow. 2002. "Indirect estimation of soil thermal properties and water flux using heat pulse probe measurements: Geometry and dispersion effects." Water Resources Research 38 (1): 7-1-7-14. https://doi.org/10.1029/2000WR000071.

Hvorslev, M.J. 1951. "Time lag and soil permeability in ground-water observations." United States Army Corps of Engineers, Waterworks Experimental Station 36.

Irvine, D.J., I. Cartwright, V.E.A. Post, C.T. Simmons, and E.W. Banks. 2016. "Uncertainties in vertical groundwater fluxes from 1-D steady state heat transport analyses caused by heterogeneity, multidimensional flow, and climate change." Water Resources Research 52 (2): 813-826. https://doi.org/10.1002/2015WR017702. 
Irvine D.J., Kurylyk B.L., Cartwright, I., Bonhamd, M., Post V.E.A., Banks, E.W., Simmons, C.T. 2017a. Groundwater flow estimation using temperature-depth profiles in a complex environment and a changing climate. Science of the Total Environment, 574, 272-281.

Irvine, D.J., M.A. Briggs, L.K. Lautz, R.P. Gordon, J.M. McKenzie, and I. Cartwright. 2017 b.

"Using diurnal temperature signals to infer vertical groundwater-surface water exchange." Groundwater 55 (1): 10-26. https://doi.org/10.1111/gwat.12459.

Israelsen, Orson W. and Reeve, Ronald C. 1944. Bulletin No. 313 - Canal Lining Experiments in the Delta Area, Utah. UAES Bulletins. Paper 348. https://digitalcommons.usu.edu/uaes bulletins/348

Jensen, J.K., and P. Engesgaard. 2011. "Nonuniform groundwater discharge across a streambed: heat as a tracer." Vadose Zone Journal 10: 98-109. https://doi.org/10.2136/vzj2010.0005.

Käser, D.H., A. Binley, A.L. Heathwaite, and S. Krause. 2009. "Spatio-temporal variations of hyporheic flow in a riffle-step-pool sequence." Hydrological Processes 23 (15): 21382149. https://doi.org/10.1002/hyp.7317.

Kearl, P.M. 1997. "Observations of particle movement in a monitoring well using the colloidal borescope." Journal of Hydrology 200 (1-4): 323-344. https://doi.org/10.1016/S00221694(97)00026-7.

Keery, J., A. Binley, N. Crook, and J.W.N. Smith. 2007. "Temporal and spatial variability of groundwater-surface water fluxes: development and application of an analytical method using temperature time series." Journal of Hydrology 336 (1-2): 1-16. https://doi.org/10.1016/j.jhydrol.2006.12.003.

Kennedy, C.D., L.C. Murdoch, D.P. Genereux, D.R. Corbett, K. Stone, P. Pham, and H. Mitasova. 2010. "Comparison of Darcian flux calculations and seepage meter measurements in a sandy streambed in North Carolina, United States." Water Resources Research 46 (9). https://doi.org/10.1029/2009WR008342.

Krause, S., T. Blume, and N.J. Cassidy. 2012. "Investigating patterns and controls of groundwater up-welling in a lowland river by combining fibre-optic distributed temperature sensing with observations of vertical hydraulic gradients." Hydrology and Earth System Sciences 16 (6): 1775-1792. https://doi.org/10.5194/hess-16-1775-2012.

Krause, S., and T. Blume. 2013. "Impact of seasonal variability and monitoring mode on the adequacy of fiber-optic distributed temperature sensing at aquifer-river interfaces." Water Resources Research 49 (5): 2408-2423. https://doi.org/10.1002/wrcr.20232.

Krause, S., F. Boano, M.O. Cuthbert, J.H. Fleckenstein, and J. Lewandowski. 2014. "Understanding process dynamics at aquifer-surface water interfaces: An introduction to the special section on new modeling approaches and novel experimental technologies." Water Resources Research 50 (2): 1847-1855. https://doi.org/10.1002/2013WR014755.

LaBaugh, J.W., Rosenberry, D.O., Winter T.C.1995.Groundwater contribution to the water and chemical budgets of williams lake, minnesota, 1980-1991. Canadian Journal of Fisheries and Aquatic Sciences, 52(4):754-767, doi: 10.1139/f95-075.

Labaky, W., J.F. Devlin, and R.W. Gillham. 2007. "Probe for measuring groundwater velocity at the centimeter scale.” Environmental Science \& Technology 41 (24): 8453-8458. https://doi.org/10.1021/es0716047.

Lautz, L.K. 2010. "Impacts of nonideal field conditions on vertical water velocity estimates from streambed temperature time series." Water Resources Research 46 (1). https://doi.org/10.1029/2009WR007917. 
Lee, D.R. 1977. "A device for measuring seepage flux in lakes and estuaries." Limnology and Oceanography 22 (1): 140-147. https://doi.org/10.4319/lo.1977.22.1.0140.

Lu, C., S. Chen, Y. Zhang, X. Su, and G. Chen. 2017. "Heat tracing to determine spatial patterns of hyporheic exchange across a river transect." Hydrogeology Journal 5 (6): 1633-1646. https://doi.org/10.1007/s10040-017-1553-9

Maurya, P.K., N. Balbarini, I. Møller, V.K. Rønde, A.V. Christiansen, P.L. Bjerg, E. Auken, and G. Fiandaca. 2018. "Subsurface imaging of water electrical conductivity, hydraulic permeability and lithology at contaminated sites by induced polarization." Geophysical Journal International 213 (2): 770-785. https://doi.org/10.1093/gji/ggy018.

McCallum, J.L., P.G. Cook, D. Berhane, C. Rumpf, and G.A. McMahon. 2012. "Quantifying groundwater flows to streams using differential flow gaugings and water chemistry." Journal of Hydrology 416-417: 118-132. https://doi.org/10.1016/j.jhydrol.2011.11.040.

Murdoch, L.C., and S.E. Kelly. 2003. "Factors affecting the performance of conventional seepage meters." Water Resources Research 39 (6). https://doi.org/10.1029/2002WR001347.

Osorno, T., Devlin, J.F. 2018. An in-well point velocity probe for the rapid characterization of groundwater velocity at the centimeter-scale. Journal of Hydrology, 557, 539-546.

Post, V.E.A., and J.R. von Asmuth. 2013. "Review: Hydraulic head measurements-new technologies, classic pitfalls." Hydrogeology Journal 21 (4): 737-750. https://doi.org/10.1007/s10040-013-0969-0.

Rasmussen, J.J., McKnight, U.S., Sonne, A.Th., Wiberg-Larsen, P., Bjerg, P.L. 2016. Legacy of a Chemical Factory Site: Contaminated Groundwater Impacts Stream Macroinvertebrates. Archives of Environmental Contamination and Toxicology, DOI 10.1007/s00244-015-0211-2

Rønde, V., U.S. McKnight, A. Th. Sonne, N. Balbarini, J.F. Devlin, and P.L. Bjerg. 2017. "Contaminant mass discharge to streams: Comparing direct groundwater velocity measurements and multi-level groundwater sampling with an instream approach." Journal of Contaminant Hydrology 206: 43-54. https://doi.org/10.1016/j.jconhyd.2017.09.010.

Rose, L., S. Krause, and N.J. Cassidy. 2013. "Capabilities and limitations of tracing spatial temperature patterns by fiber-optic distributed temperature sensing." Water Resources Research 49 (3): 1741-1745. https://doi.org/10.1002/wrcr.20144.

Rosenberry, D.O., Morin, R.H. 2004. Use of an electromagnetic seepage meter to investigate temporal variability in lake seepage. Ground Water, 42(1), 68-77.

Rosenberry, D.O. 2005. "Integrating seepage heterogeneity with the use of ganged seepage meters." Limnology and Oceanography: Methods 3 (2): 131-142. https://doi.org/10.4319/lom.2005.3.131.

Rosenberry, D.O. 2008. "A seepage meter designed for use in flowing water." Journal of Hydrology 359 (1-2): 118-130. https://doi.org/10.1016/j.jhydrol.2008.06.029.

Rosenberry, D.O. and J.W. LaBaugh. 2008. "Field techniques for estimating water fluxes between surface water and ground water." United States Geological Survey Techniques and Methods 4-D2.

Rosenberry, D.O., R.W. Sheibley, S.E. Cox, F.W. Simonds, and D.L. Naftz. 2013. "Temporal variability of exchange between groundwater and surface water based on high frequency direct measurements of seepage at the sediment-water interface." Water Resources 
Rugge, K., Hofstetter, T.B., Haderlein, S.B., Bjerg, P.L., Knudsen, S., Zraunig, C., Mosbaek, H., Christensen, T.H. 1998. Characterization of predominant reductants in an anaerobic leachate-contaminated aquifer by nitroaromatic probe compounds. Environmental Science and Technology, 32(1), 23-31.

Schillig, P.C. 2012. "VelProbePE: An automated spreadsheet program for interpreting point velocity probe breakthrough curves." Computers and Geosciences 39: 161-170. https://doi.org/10.1016/j.cageo.2011.06.007.

Schillig, P.C., J.F. Devlin, C.D. McElwee, K. Walter, and B. Gibson. 2014. “Assessment of density-induced tracer movement in groundwater velocity measurements with point velocity probes (PVPs)." Ground Water Monitoring and Remediation 34 (4): 44-50. https://doi.org/10.1111/gwmr.12075.

Schmidt, C., M. Bayer-Raich, and M. Schirmer. 2006. "Characterization of spatial heterogeneity of groundwater-stream water interactions using multiple depth streambed temperature measurements at the reach scale." Hydrology and Earth System Sciences 10: 849-859. https://doi.org/10.5194/hess-10-849-2006.

Schmidt, C., B. Conant, M. Bayer-Raich, and M. Schirmer. 2007. "Evaluation and field-scale application of an analytical method to quantify groundwater discharge using mapped streambed temperatures." Journal of Hydrology 347 (3-4): 292-307. https://doi.org/10.1016/j.jhydrol.2007.08.022.

Schulz, H. 2017. Application of the streambed-Point Velocity Probe for investigating contaminant discharge to streams. Master's thesis, Technical University of Denmark Department of Environmental Engineering, $125 \mathrm{pp}$.

Selker, J.S., N. van de Giesen, M. Westhoff, W. Luxemburg, and M.B. Parlange. 2006a. "Fiber optics opens window on stream dynamics.” Geophysical Research Letters 33 (24). https://doi.org/10.1029/2006GL027979

Selker, J.S., L. Thévenaz, H. Huwald, A. Mallet, W. Luxemburg, N. van de Giesen, M. Stejskal, J. Zeman, M. Westhoff, and M.B. Parlange. 2006b. "Distributed fiber-optic temperature sensing for hydrologic systems." Water Resources Research 42 (12). https://doi.org/10.1029/2006WR005326

Shanafield, M., Hatch, C.E., Pohll, G. 2011. Uncertainty in thermal time series analysis estimates of streambed water flux. Water Resources Research, v. 47, W03504, doi:10.1029/2010WR009574.

Shaw, R.D., and E.E. Prepas. 1990. “Groundwater-lake interactions: II. Nearshore seepage patterns and the contribution of ground water to lakes in Central Alberta." Journal of Hydrology 119 (1-4): 121-136. https://doi.org/10.1016/0022-1694(90)90038-Y.

Solder, J.E., T.E. Gilmore, D.P. Genereux, and D.K. Solomon. 2016. "A tube seepage meter for in situ measurement of seepage rate and groundwater sampling." Groundwater 54 (4): 588-595. https://doi.org/10.1111/gwat.12388.

Sonne, A.Th., U.S. McKnight, V.K. Rønde, and P.L. Bjerg. 2017. "Assessing the chemical contamination dynamics in a mixed land use stream system." Water Research 125: 141-151. https://doi.org/10.1016/j.watres.2017.08.031.

Su, G.W., B.M. Freifeld, C.M. Oldenburg, P.D. Jordan, and P.F. Daley. 2006. "Interpreting velocities from heat-based flow sensors by numerical simulation." Groundwater 44 (3): 386-393. https://doi.org/10.1111/j.1745-6584.2005.00147.x. 
Tyler, S.W., J.S. Selker, M.B. Hausner, C.E. Hatch, T. Torgersen, C.E. Thodal, and S.G. Schladow. 2009. "Environmental temperature sensing using raman spectra DTS fiberoptic methods." Water Resources Research 45 (4). https://doi.org/10.1029/2008WR007052.

Urumovic, K., and K. Urumovic Sr. 2016. "The referential grain size and effective porosity in the Kozeny-Carman model.” Hydrological Earth System Science 20 (5): 1669-1680. https://doi.org/10.5194/hess-20-1669-2016.

van de Giesen, N., S.C. Steele-Dunne, J. Jansen, O. Hoes, M.B. Hausner, S. Tyler, and J.S. Selker. 2012. "Double-ended calibration of fiber-optic raman spectra distributed temperature sensing data." Sensors 12 (5): 5471-5485. https://doi.org/10.3390/s120505471.

Westhoff, M.C., M.N. Gooseff, T.A. Bogaard, and H.H.G. Savenije. 2011. "Quantifying hyporheic exchange at high spatial resolution using natural temperature variations along a first-order stream." Water Resources Research 47 (10). https://doi.org/10.1029/2010WR009767.

Woessner, W.W. and K.E. Sullivan. 1984. "Results of seepage meter and mini-piezometer study, Lake Mead, Nevada.” Ground Water 22 (5): 561-568. https://doi.org/10.1111/j.17456584.1984.tb01425.x.

Zamora, C. 2006. Estimating rates of exchange across the sediment/water interface in the lower Merced River, CA. MS thesis. California State University, Sacramento, 102 pp. 